\title{
Pengaruh Jenis Pelarut Terhadap Nilai Sun Protection Factor Maserat Daun Kelor
}

\section{Effect Of Solvent Type On Sun Protection Factor Maserat Moringa}

\author{
Venny Diah Ningsih, Isma Oktadiana \\ Program Studi Farmasi, Fakultas Ilmu Kesehatan, Universitas Ibrahimy \\ Email: venny.dingsih@gmail.com
}

\begin{abstract}
ABSTRAK
Daun kelor merupakan salah satu bagian tanaman yang memiki banyak khasiat untuk kesehatan salah satunya ialah sebagai antioksidan. Salah satu kandungan daun kelor yang memiliki aktivitas sebagai antioksidan aialah quercetin. Quercetin Bersifat polar dan tidak larut dalam air. Tujuan dari penelitian ini ialah untuk mengetahui pengaruh jenis pelarut terhadap nilai SPF maserat daun kelor. Metode penelitian eksperimental dengan desain analisis deskriptif, dimulai dengan pembuatan maserat daun keor, penyaringan, dan pengujian Nilai SPF, menggunakan Spektrofotometer UV-Vis. Berdasarkan percobaan yang telah dilakukan didaptkan hasil bahawa pelarut methanol $(6,75)$ memberikan nilai SPF lebih tinggi dibandingkan dengan dengan pelarut etanol $(5.32)$.
\end{abstract}

Kata Kunci : Daun Kelor, Pelarut, SPF

\section{ABSTRACT}

Moringa leaves are one part of the plant which has many health properties one of which is an antioxidant. One of the content of Moringa leaves which contains antioxidant activity is quercetin. Quercetin Is polar and insoluble in air. The purpose of this research was to find out the type of solvent against the SPF value of Moringa leaf maserat. An experimental research method with a descriptive analysis design, starting with making Moringa leaf maserat, screening, and testing the SPF value, using a UV-Vis spectrophotometer. Based on the experiments that have been carried out the methanol (6.75) solvent elds a higher SPF value compared to ethanol (5.32).

Keyword: Moringa Leaf, Solvent, SPF.

\section{PENDAHULUAN}

Tanaman Kelor (Moringa oliefera) merupakan tanaman yang mudah tumbuh di dataran rendah. Daun kelor sendiri memiliki banyak aktivitas biologis salah satunya ilah sebagai anti oksidan. Kandungan pada pada daun kelor yang memiliki aktivitas sebagai anti oksidan salah satunya ialah quercetin. Dimana menurut Hardianti (2015) kekuatan antioksidan quercetin 4-5 kali lebih besar dibandingkan dengan vitamin $\mathrm{C}$.

Berdasarkan penelitian yang dilakukan oleh Rahmat (2009) menyebutkan bahwa dalam setiap 100 gram simplisia basah daun kelor terdapat 384,61 mg quercetin. Dimana berdasarkan hal tersebut tanaman kelor menjadi tanaman yang sangat potensial untuk dijadikan suatu produk yang antioksidan yaitu produk tabir surya. 
Produk tabir surya adalah produk yang digunakan untuk melindungi kulit dari sengatan sinar matahari. Dimana pada produk tabir surya digunakan nilai SPF (Sun Protection Factor) untuk mengetahui nilai proteksi senyawa aktif terhadap paparan matahari.

Paparan Sinar Matahari (Spektrum UV) terbagi menjadi tiga kelompok berdasarkan panjang gelombang. Panjang gelombang 200-290 nm merupakan sinar UV-C. Panjang gelombang 290-320 nm merupakan sinar UV-B. Panjang gelombang 320-400 nm merupakan sinar UV-A. Tidak semua radiasi sinar UV dari matahari dapat mencapai permukaan bumi. Sinar UV-C yang memiliki energi terbesar tidak dapat mencapai permukaan bumi karena mengalami penyerapan lapisan ozon (Balakhrisnan and Nithya, 2011). Lebih dari $90 \%$ radiasi matahari mencapai bumi adalah UV-A yang berpenetrasi ke dalam menuju epidermis dan dermis pada kulit. UV-A 1000 kali lebih efektif menghasilkan efek tanning (kecoklatan) dibandingkan dengan UV-B. Paparan UV-A jangka panjang dapat menyebabkan kulit terbakar dan membahayakan struktur dermis. Hal ini dapat menyebabkan kerusakan protein selular, lipid, dan sakarida kemudian menyebabkan nekrosis dari sel endothel kemudian merusak pembuluh darah di dermal sehingga merubah struktur DNA dan menyebabkan kanker (Balakhrisnan and Nithya, 2011).

Berdasarkan hal tersebut Tujuan Dari peneltian ini ialah ingin mengetahui besaran nilai SPF yang dihasilkan oleh maserat daun kelor dengan menggunakan perbandingan pelarut.

\section{METODE PENELITIAN}

Penelitian ini merupakan penelitian eksperimental dengan desain analisis deskriptif. Penelitian dilakukan di Laboratorium Kimia Dasar, Prodi Farmasi, Fakultas Ilmu Kesehatan, Universitas Ibrahimy pada Bulan Februari-Agustus 2019.

Alat yang diginakan dalam penelitian ini adalah sebagai berikut: Oven (Memmert UN 55), Hotplate and Stirrer (Thermo Scientific), Spektrofotometer Uv-Vis (Thermo Gynesis 150) dan Alat Gelas (Iwaki Asahi Glass), dengan bahan utama Daun Kelor (didapatkan dari wilayah pondok pesantren sukorejo), Pelatut Etanol $96 \%$ dan Pelarut Metanol $96 \%$ (Cv. Makmur Sejati Malang). Kemudian pembuatan maserat masing-masing sebanyak 50 gram simplisia daun kelor dimaserasi dengan menggunakan etanol 
dan methanol (1:10) selam 12 jam dengan pengadukan menggunakan stirrer selama 15 menit. Selanjutnya maserasi (rendaman) disaring menggunakan kertas saring 2 lapis sehingga didapatkan maserat. Langkah terakhir pengujian Nilai SPF, Pengujian nilai SPF maserat daun kelor menggunakan Spektrofotometer UV-Vis dengan cara maserat daun kelor di ukur absorbansinya pada Panjang gelombang $290 \mathrm{~nm}, 295 \mathrm{~nm}$, 300 nm, 305 nm, 310 nm, 315 nm, dan 320 nm. Selanjutnya nilai Absorbansi yang didapatkan dimasukkan kedalam persamaan SPF sehingga didapatkan Nilai SPF dari maserat daun kelor menggunakan rumus sebagai berikut:

$$
\mathrm{SPF}=\mathrm{CF} \times \sum_{290}^{320} \mathrm{EE}(\lambda) \times \mathrm{I}(\lambda) \times \operatorname{Abs}(\lambda)
$$

\section{Keterangan :}

$$
\begin{aligned}
& \mathrm{CF} \text { : Correction Factor (10) } \\
& \mathrm{EE}: \text { Erythemal effect spectrum } \\
& \mathrm{I}: \text { Intensitas spektrum matahari pada } \\
& \quad \text { panjang gelombang } \\
& \text { Abs : Absorbansi produk tabir surya }
\end{aligned}
$$

\section{HASIL DAN PEMBAHASAN}

Penentuan Nilai SPF maserat daun kelor menggunakan spektrofotometer Uv-Vis, dapat dilihat pada tabel 1:

Tabel 1. Hasil Uji nilai SPF maserat daun kelor menggunakan spektrofotometer Uv-Vis.

\begin{tabular}{cccccc}
\hline Pelarut & $\begin{array}{c}\text { Panjang } \\
\text { Gelombang }\end{array}$ & Absorbansi & EE x I & $\begin{array}{c}\text { CF x Abs x } \\
\text { (EE x I) }\end{array}$ & SPF \\
\hline \multirow{6}{*}{ Etanol } & 290 & 3.907 & 0.015 & 0.58605 & \\
& 295 & 3.812 & 0.0817 & 3.114404 & \\
& 300 & 3.794 & 0.2874 & 10.903956 & 5.32532 \\
& 305 & 3.685 & 0.3278 & 12.07943 & \\
& 310 & 3.658 & 0.1864 & 6.818512 & \\
& 315 & 3.701 & 0.0837 & 3.097737 & \\
Metanol & 320 & 3.762 & 0.018 & 0.67716 & \\
& 290 & 4.945 & 0.015 & 0.74175 & \\
& 295 & 5 & 0.0817 & 5.085 & \\
& 300 & 4.72 & 0.2874 & 13.56528 & \\
& 305 & 4.689 & 0.3278 & 15.370542 & 6.75553 \\
& 310 & 4.658 & 0.1864 & 8.682512 & \\
& 315 & 4.76 & 0.0837 & 3.98412 & \\
\hline
\end{tabular}

Pengujian SPF dengan perbandingan

pelarut bertujuan untuk mengetahui pengaruh pengunaan jenis pelarut terhadap nilai SPF yang dihasilkan. Pelarut yang digunakan ialah pelarut polar ( etanol dan metanol) dengan metode ekstraksi maserasi. 
Maserasi merupakan jenis ekstraksi secara dingin yang digunakan dengan tujuan mencegah kerusakan komponen kimia yang tidak tahan terhadap pemanasan (Syukur, et al., 2011). Sehingga metode ini cocok untuk mengekstrak zat aktif antioksidan yang merupakan komponen kimia yang tidak tahan terhadap panas.

Tujuan maserasi adalah untuk menarik semua komponen kimia yang terdapat dalam sampel, dimana pelarut akan menembus dinding sel dan masuk ke dalam rongga sel yang mengandung senyawa aktif. Senyawa aktif akan larut karena adanya perbedaan konsentrasi antara larutan senyawa aktif di dalam dan di luar sel.

Pelarut etanol dipilih karena karena etanol merupakan pelarut universal yang dapat menyari senyawa polar, nonpolar dan semi polar. Menurut Poelang 2007 dalam Febrianti 2014 pelarut etanol 96\% merupakan pelarut yang paling maksimal dalam menarik senyawa fenolik dan flavonoid dibandingkan dengan pelarut air atau campuran etanol air. Sebagai perbandingan digunkan pelarut metanol. Metanol merupakan senyawa polar yang dapat melarutkan hampir semua metabolit sekunder Selain itu, dibandingkan dengan pelarut lain metanol memiliki sifat mudah menguap sehingga pelarut pada ekstrak lebih mudah diuapkan tanpa merusak kandungan kimia dalam ekstrak (Hardianti, 2015)

Simplisia yang sudah direndam selanjutnya di saring menggunakan kertas saring. Maserat yang didapatkan selanjutnya di analisa menggunakan Spektrofotometer UV-vis pada Panjang gelombang UV B sehingga didapatkan nilai absorbansi untuk mengetahui nilai SPF yang dihasilkan.

Berdasarkan pengujian yang dilakukan didapatkan nilai SPF dari maserat daun kelor dengan pelarut etanol sebesar 5.32532 dan pelarut metanol sebesar 6.75553 . Berdasarkan penilaian SPF menurut FDA (Food And Drug Administration) besaran nilai SPF yang dihasilkan maserat daun kelor dengan pelarut etanol (5.32532) termasuk dalam tipe proteksi sedang sedangkan pada pelarut metanol (6.75553) termasuk dalam kategori ekstra. Dengan demikian dapat dikatakan bahwa daun kelor sangat berpotensi untuk diformulasikan dalam sediaan tabir surya.

\section{SIMPULAN DAN SARAN}

Berdasarkan hasil yang didapatkan dapat disimpulkan bahwa pengujian nilai SPF maserat daun kelor menggunakan pelarut Metanol memberikan nilai SPF Lebih tinggi dibandingkan dengan pelarut 
Etanol. Pada penelitian selanjutnya diharapkan dilakukan pengujian SPF daun kelor pada sediaan tabir surya.

\section{DAFTAR PUSTAKA}

Balakhrisnan KP and Narayanaswamyi Nithya.2011. Botanicals as sunscreens: their role in prevention of photoaging and skin cancer. International journal of research in cosmetic science universal research publiations. All right reserved, 2011: 1 (1): 112.

Febrianti, Nurinda Wulan. 2014. Aktivitas Antibakteri ekstrak etanol dan fraksi-fraski dari ekstrak etanol daun kelapa sawit (Elaeis Guineensis jacq) terhadap bakteri staphylococcus aureus dan basillus subtilis serta profil KLT nya. Naskah Publikasi.

Hardianti, F. 2015. Pemanfaatan aktivitas antioksidan ekstrak daun kelor (moeinga oliefera) dalam sediaan hand body cream. [skripsi]. Jakarta: program studi kimia UIN Syarif Hidayatullah.

Rahmat, H. 2009. Identifikasi Senyawa Flavonoid Pada Sayuran Indogenious Jawa Barat [skripsi]. Bogor: Program Teknologi Pertanian Institut Pertanian Bogor.

Syukur, R., alam, G., Mufidah., Rahim, A., Tayeb, R. 2011. Aktivitas Antiradikal bebas beberapa ekstrak tanaman familia fabaceae. JST kesehatan Vol. 1 No.1: 61-67. ISSN 1411. 